\title{
Ebû Bekir ez-Zübeydî'nin Pedagojik Açıdan Arap Dilinin Öğretimindeki Yeri
}

Arş. Gör. Ramazan Kılıç

Hitit Üniversitesi, İlahiyat Fakültesi

Arap Dili ve Belagati Ana Bilim Dal

Öz

ramazannkilicc@hotmail.com

$\mathrm{Bu}$ araştırma, dünya medeniyet tarihine ciddi katkılar sunmuş Endülüs Emevi Devleti'nin uhdesinde yetişen en büyük dilcilerden Ebû Bekir ez-Zübeydî ve onun yabancı dil öğretim anlayışı hakkındadır. Zübeydî, günümüzden yaklaşık XI asır kadar önce yaşamış ve çeşitli alanlarda eserler vermiş bir alimdir. Özellikle lügat alanında ihtiyaç duyulan ve dönemin şartlarına hitap edebilen birbirinden değerli eserlerin sahibidir. Bu yapıtlardan birisi olan Kitâbü'l-Vâdıh, Endülüs Emevi Devleti zamanında gereksinim olan Arapçanın öğrenilip öğretilmesine yönelik tasarlanmış bir kitaptır. Arapçanın yabancı bir dil olarak öğretilmesi olgusu, günümüz eğitim sisteminin temel problemleri arasında kabul edilir. Geçmişte de araştırma konusu olan Arapçanın öğretimine Zübeydî, kendi dilci kimliği ile yaklaşmışır. Bu bakımdan çalışmada, Vâdıh isimli eserin eğitsel olarak nasıl bir yapıda tasarlandığı, klasik ve modern yabancı dil eğitimi alanına neler katabileceği ortaya konacaktır. Betimleyici bir araştırma yöntemi takip edilerek Vâdıh eserinin pedagojik dil eğitimi alanına katkıları tartışılacaktır.

Anahtar Kelimeler: Arap dili, yabancı dil eğitimi, Endülüs, Ebû Bekir ez-Zübeydî, Kitâbu'l-Vâdıh.

\section{The Place of Abû Bakr al-Zubaidî in the Teaching of Arabic Language from a Pedagogical Aspect}

\section{Abstract}

This research is about Abû Bakr al-Zubaidî, one of the greatest linguists of the Andalusian Umayyad Empire, and his understanding of foreign language teaching. Zubaidî is a scholar who lived around XIth century and brought in various scientific activities. He is the owner of valuable works which are needed especially in the field of language and which can conform to the conditions of the period. One of these works, the Kitâbu'l-Wâdıh is a book designed to learn and teach Arabic, a necessity in the time of the Umayyad Empire. Teaching Arabic as a foreign language is accepted as one of the basic problems of today's education system. As it was also discussed in the past, Zubaidî approached the issue of teaching Arabic with his own linguistic identity. In this respect, how al-Wâdıh is designed in an educational way and what it can add to foreign language education in the modern and classic world will be revealed. In this context, a descriptive research method will be followed and the contributions of Wâdıh to pedagogical language education will be discussed.

Keywords: Arabic language, foreign language education, Andalusia, Abû Bakr alZubaidî, Kitâbu'l-Wâdıh. 


\section{GíRIŞ}

Arap dili alanındaki ilk sistematik çalışmalar M. VII. Yüzyılda Halîl b. Ahmed (ö.175/791) ile başlamıştır. el-Halîl ve öğrencilerince Basra'da yütrütülen ve ardından Kufe'ye sıçrayan çalışmaların odak noktası, Arap dilini kayıt altına alma ve sistematik bir yapıya sokma gayesi olmuştur. Kur'an-1 Kerim'in inmesi ve İslam dininin yayılmasıyla öte yandan kutsal kitap merkezli Tefsir, Hadis, Fıkıh ve Kelam gibi disiplinler ortaya çıkmıştır. Bu ilim dallarının tamamına yakını, farklı bağlam ve kapsamlarda dille ilişkili meseleleri konu edinmek durumunda kalmıştır. Bu minvalde İslam tarihindeki ilk ilim ve düşünce insanları, tek bir alanda uzmanlaşmamış; aynı anda birçok bilim dalına vakıf olma gerekliliği hissetmiştir.

Arap dili sahasında yapılan araştırmaların kapsamı, eyyâmü'l-'arab, ahbâr, nevâdir, gramer (nahiv-sarf), edebiyat ve anlam bilim konularından meydana gelir. Bu alanların temel noktası Arapça hakkındaki dil malzemelerini toplayıp derleme üzerine kuruludur. Dilin temel yapısının tespiti üzerine yürütülen bu çalışmalara ek olarak kimi dilciler, onun eğitsel yönünü de ele almışlardır (Amayira, 1996, s. 66). Fetihlerin artmasıyla beraber anadili Arapça olmayan toplulukların İslamiyet'le karşılaşması da bu tür çalışmaların gerçekleşmesini zorunlu hale getirmiştir. Klasik Arap dili tarihine bakıldığında Arap dili çalışmalarını yürüten dilcilerin büyük çoğunluğunun Arap dışı unsurlardan oluştuğu görülmektedir (Kılıçlı, 1986, s. 118-119). Ayrıca tarihsel olarak Arap dili araştırmalarının sırasıyla Basra, Kufe, Bağdat, Endülüs ve Mısır gibi şehir ve devletlerde ortaya çıkması da Arap dilinde pedagojik çalışmaların ortaya çıkmasının gerekliliğini gösterir niteliktedir (Dayf, 1968, s. 5-8).

Arap dilini pedagojik bir perspektifte ele alan belli bazı eserler mevcuttur. Bunlardan bazıları sırasıyla şu şekildedir;

- Halef el-Ahmar (180/796) Mukaddimetü fi'n-Nahv

- $\quad$ Ali b. Hamza Kisâî (189/805) Muhtasar fi'n-Nahv ${ }^{1}$

- Yahyâ b. Mübârek el-Yezîdî (202/817) Muhtasar fi'n-nahv²

- $\quad$ Ebû 'Ömer el-Cermî (225/840) el-Ferh ${ }^{3}$

- Muhammed b. Sa'dân ed-Darîr (231/846) Kitâbü'l-Muhtasari'n-Nahvi

- Abdullah b. Yahyâ el-Yezîdî (237/851) Muhtasar fi'n-Nahvi

- $\quad$ Ebû Bekir Muhammmed İbnü's-Serrâc (316/929) el-'Usûl fi'n-Nahv

- İbnü's-Serrâc (316/929) el-Mûcez fi'n-Nahv

- Ebû Bekir ibnü'l-Enbârî (328/940) el-Vâdıh fi'n-Nahv/el-Muvaddihu fi'n-Nahvii ${ }^{5}$

- Ebü'l-Kâsım ez-Zeccâcî (337/949) el-Cümel fi'n-Nahv

\footnotetext{
${ }^{1}$ Bu esere günümüzde ulaşılamamakla beraber kaynaklar mevcudiyetinden söz eder. bkz. İbnü'l-Enbârî, 1985, s. 70; el-Hamevî, 1993, s. IV/1752.

${ }^{2}$ Halife Me'mûn'un çocukları için kaleme alınan bu esere günümüzde henüz ulaşılamamıştır. bkz. Yezîdî, 1978, s. Eserin mukaddimesi.

${ }^{3}$ Bu eser Sîbeveyhi'nin el-Kitâb'ını özetleme amacıyla kaleme alınsa da günümüze ulaşamamıştır. bkz. İbn Hallikân, 1972, s. II/485.

${ }^{4}$ Günümüze dek bu esere ulaşılamamıştır. bkz. Ya'kûb, 1971, s. VIII/276.

${ }^{5}$ Günümüzde böyle bir esere ulaşılamamakla beraber İbnü'n-Nedîm bu kitabın mevcudiyetinden kendi eserinde bahsetmiş "Kitabü'l-Vâdıh fi'n-Nahvi eseri büyük bir eserdir" şeklinde bir yorum yapmaktan geri durmamıştır. bkz. İbnü'n-Nedîm, [t.y.], s. 82.
} 
- Ebû Ca'fer en-Nehhâs (338/950) et-Tüffâha fi'n-Nahv

- Ebû Bekir ez-Zübeydî (379/989) Kitâbü'l-Vâdıh/el-Vâdih fî ‘lilmi'l-‘Arabiyye

- Ebü'l-Feth ‘Osmân b. Cinnî (392/1002) el-Lem’a fi'l-'Arabiyye

$\mathrm{Bu}$ araştırmanın ana temasını klasik dönemde Arap dilinin öğretimi hakkında yürütülen çalışmaların Endülüs Emevi Devleti'ndeki temsilcisi Ebû Bekir ez-Zübeydî ve onun Kitâbu'l-Vâdıh isimli eseri oluşturmaktadır.

\section{EBÛ BEKİR EZ-ZÜBEYDÎ VE YAŞADIĞI DÖNEM}

\subsection{Endülüs Emevi Devleti}

Endülüs, bugünkü haliyle İspanya'da hâlâ kullanılmakta ve Almeria (el-Meriye), Granada (Gırnata), Jaén (Ceyyân), Cordoba (Kurtuba), Sevilla (İşbîliye), Huelva (Velbe), Malaga (Mâleka) ve Cadiz (Kādis) vilâyetlerini içine alan bölgeyi ifade etmektedir (Özdemir, 1995, s. 211). İslam tarihinde İspanya'nın fethi Târık b. Ziyâd (102/720) tarafından 92/711 yılında gerçekleştirilmiştir (Kûtiyye, 1989, s. II/35). Bu dönem İspanya'da sürdürülen fetih hareketleri Paris sınırına kadar dayanmış, Müslümanlar Avrupa'da ciddi bir fetih başarısına ulaşmıştır (Özdemir, 1995, s. 212).

Tarihsel ve siyasi açıdan Endülüs, çeşitli devletlere ve dönemlere evirilmiştir. Endülüs'ün, başkenti Şam'da bulunan Emevi devletinin bir vilayeti olarak yönetildiği Valiler Dönemi 92-138/711-755 yıllarını kapsamaktadır. 139-423/756-1031 tarihleri arasını kapsayan Endülüs Emevi Devleti döneminde artık Endülüs, kendi başına müstakil bir devlet hüviyetine kavuşmuştur. Devam eden dönemlerde ise Endülüs giderek zayıflamış, "şehir devletleri" yapısında idare edilmiş ve 898/1492 yılında bilfiil yıkılmıştır (Özdemir, 1996, s. 233-254; Yildırım 2007, s. 3-7).

Endülüs'ün insan tipolojisi bölgedeki (Avrupalı) yerli halk, Kuzey Afrika'dan gelen Berberiler ve Araplardan oluşmaktaydı. Bu nüfus kitlesi tarafından konuşulan diller ise Vulgar Latince (İspanyolca, Portekizce, Fransızca, İtalyanca, Romence), Berberice ve Arapça olmuştur. Bu denli kozmopolit bir ortamda Arapça, IX. yüzyılda resmi dil olarak kabul edilmiştir. Siyasi bakımdan Arapça, her ne kadar diğer dillere karşı bir üstünlük yakalamış olsa da burada yaşayan halk (Müslümanlar da dahil), Latinceyi de anadil olarak edinmekteydi (Özdemir, 1995, s. 218-219).

Endülüs, siyasi tarihi bakımından (genel manada) kuruluşundan yıkılışına dek taht kavgaları ve nesep çatışmalarına sahne olmuş, uzun süreli siyasi bir istikrara tam manada kavuşamamıştır. Zübeydî́nin yaşadığı süre zarfında Endülüs yönetiminin başında III. Abdurrahmân (350/961), II. Hakem (366/976) ve II. Hişâm (403/1013) yer almıştır. Bu hükümdarlar Endülüs tarihinin en parlak dönemlerini yaşatan yönetim erkleri olarak kabul edilir. Zira Endülüs devletindeki karışıklıkları en başarılı şekilde bastıranların başında III. Abdurrahmân gelir. Bu hükümdar, "tek bir ümmet" sloganını şiar edinerek her düşünce ve çeşitten insanın Endülüs'e gelmesine; eğitimin en kesin şekilde yaygınlaştırılmasına azami önem vermiştir. 350/961 senesinde III. Abdurrahmân vefat ederken; bilgin kişiliği ve bilime değer veren oğlu II. Hakem hükümdar olmuştur (Özdemir, 1995, s. 213). Zübeydî’nin ilmî kişiliğinin oluşumunda III. Abdurrahmân ve II. Hakem gibi siyasilerin etkileri yadsınamaz. Bu durum, siyasi gücün bilim insanlarının yetişmesi ve devletlerin kalkınmasında oynadığı role de güzel bir örnektir.

SEFAD, 2019; (42): 177-196 
Ana vatanlarından uzaklarda yaşasalar da Arapların dili, kültürü, mizacı ve özellikleri Endülüs diyarında hayatın vazgeçilmezlerinden olmuştur. Bu durum Endülüs'ün mevcudiyetince aralıksız olarak devam etmiştir (es-Seyyid, 1971, s. 123). Öte yandan Arap olmayan unsurlarla yapılan çok sayıda evlilik, yeni yetişen nesillerin bazı açılardan farklılaşmasına sebep olmuştur. Bunların başında da konuşulan dil gelir. Arapça, Ortadoğu'daki yapısından uzaklaştığı bu bölgede ötekileşmiş ve farklılaşmıştır. Ancak Arapların ortak noktada buluştukları Fasîh dil yapısı; yazı, eğitim ve hutbelerin müşterek dili olarak Endülüs'te de kullanılmıştır. Hayatın genelinde konuşulan dil ('ammîce) ise çeşitli sebeplerle farklılaşmış ve böylece bir dil varyantı olarak Endülüs Arapçası ortaya çıkmıştır. Bu sebeple Fasih Arapça ve Endülüs Arapçası arasında yaşanan farklılaşmaları konu edinen eserler kaleme alınmıştır. Bunlardan ancak bir kısmı günümüze dek ulaşabilmiştir (es-Seyyid, 1971, s. 124).

Arap dili hakkında yapılan çalışmalardan bir kısmı ise Arapçanın öğretilip öğrenilmesine yöneliktir (Seyyid, 1971, s. 125). Zira Arapçanın ana vatanı Arap Yarımadası' dan uzak bu diyarda Arapçanın bölge insanına öğretilmesi asli bir ihtiyaç halini almıştır. Bu faaliyetlerin Endülüs'teki en önemli temsilcilerinin başında da Ebû Bekir ezZübeydî gelmektedir.

\subsection{Ebû Bekir Zübeydî'nin Hayatı ve İlmi Şahsiyeti}

Tam adıyla Ebû Bekir Muhammed b. el-Hasan b. Abdullâh b. Mezhic b. Muhammmed b. Abdullâh b. Beşer ez-Zübeydî'dir (İbn Hallikân, 1972, s. IV/372; es-Suyûtî, 1987, s. I/84). 316/928 yılında İşbîliye (Sevilla) kentinde doğmuştur (Humeydî, 1966, s. I/48; el-Yemânî, 1986, s. 307). Zübeydî ismi, tarihsel açıdan aslen Yemende bulunan ve sahabeden de bazılarının mensubu olduğu bir kabileye dayandırılır. Mezhic ise Yemende bulunan kızıl tepelere verilen ismin adıdır (İbn Hallikân, 1972, s. IV/372; et-Temîmî, 1977, s. VI/263).

Zübeydî, ilk eğitimini babasından almıştır (Zübeydi 2000, s. 12). Babası dışında eğitim gördügü hocaları arasında Ebû 'Ali İsmâil el-Kâlî ve Abdullâh er-Riyyâhî gibi isimler de vardır (Hamevî, 1993, s. VI/2519; ez-Zehebî, 1985, s. XVI/417). Daha çok İbn İklîlî olarak meşhur olan oğlu Ebu'l-Velîd, bizzat babası tarafından yetiştirilmiş ve babası ardından İşbîliye kadılığını yürütmüştür (et-Temîmî, 1977/VI, 265; el-Kıftî, 1982, s. III/109). Dönemin hükümdarı II. Hakem, oğlu veliaht prens II. Hişâm'ı ve Kurtuba'lıları eğitmesi amacıyla Zübeydi'nin İşbîliye'den başkent Kurtuba'ya gelmesini talep etmiş ve onu gelmeye razı etmiştir (İbn Hallikân, 1972, s. IV/372; Hamevî, 1993, s. VI/2519; Zehebî, 1985, s. XVI/417). Sonrasında ise Zübeydî, kendi doğduğu şehir olan İşbîliye'ye dönmek istese de hükümdar, Zübeydî'nin bu taleplerini geri çevirmiştir (el-Yemânî, 1406, s. 307). Kaynaklarda Zübeydi'nin İşbîliye de bir cariyeye aşık olduğu ve bu yüzden geri dönmek istediği de zikredilir. Devlet erkanının Kurtuba'dan ayrılmasına sıcak bakmadığı Zübeydî ise aynı zamanda şiir alanındaki ustalığı ile bu cariyeye şiirler bestelemiştir (el-Mağribî, 1955, s. I/256; Feyrûzâbâdî 2000, s. 262). Devlet yönetimiyle sıkı ilişkiler geliştiren Zübeydî, bu sayede sınırsız ilmi ve dünyevi imkanlara mazhar olmuş, İşbîliye kadılığı ve polis teşkilatı amirliği görevlerini yürütmüştür (İbn Hallikân, 1972, s. IV/372; el-Hanbelî, 1986, s. IV/418). Zübeydî'nin nahiv, irab, anlambilim, nevâdir, siyer ve ahbâr konularında alanının en tecrübeli kişilerinden değerli bir ilim adamı olduğu kabul edilir (İbn Hallikân, 1972, s. IV/372; Zehebî, 1985, s. XVI/418). Kaynaklarda hakkında olumsuz herhangi bir rivayete rastlanılmayan bu ilim insanı 379/989 yılında doğum yeri olan İşbîliye'de vefat etmiştir (Hamevî, 1993, s. VI/2519; Yemânî, 1406, s. 307; Zehebî, 1985, s. XVI/417). 


\subsection{Ebû Bekir ez-Zübeydî'nin Eserleri}

İrab, fikıh, dil ve belâgat gibi alanlarda araştırmalar yapan Zübeydî'nin kaleme aldığ1 eserlere değinmekte fayda bulunduğundan bunlardan bazıları hakkında bilgi verilecektir:

1.3.1. Muhtasaru'l-'ayn: Kaynaklarda bu eserin yazılış amacının Halîl b. Ahmed'in Kitabü'l-Ayn adlı eserini özetlemek ve sorunlu görünen yerlerini açıklamak olduğu nakledilir. Başka bir görüşe göre ise bu kitap el-Halil'in eserindeki hataların ortaya konması amacıyla yazılmıştır (Suyûtî, 1987, s. I/79). Hamevî, Batıda (Mağrib) Zübeydî'nin eserlerine gıpta edildiği ve daha iyisini yazmak üzere kıyasıya çabaların harcandığını, bu eserlerin başında da Muhtasar'in geldiğini nakleder (Hamevî, 1993, s. VI/2519).

1.3.2. Tabakâtü'n-nahviyyîn ve'l-lügaviyyîn: Bu eser, "Ahbâru'n-nahviyyîn" ve "Tabakâtü'n-nühhât ve'l-lügaviyyîn" ismiyle de bilinmektedir (Yemânî, 1406, s. 307; Zehebî, 1985, s. XVI/418). Zübeydî, biyografik yapıdaki bu eserinde Halil b. Ahmed'den başlayarak, kendi hocası Yahya er-Rebahi'ye kadar Arap dili alanında emeği geçen 296 dilciyi tabakalar halinde ele alır. Gayet sistematik şekilde tasarlanan eserde Basralı nahivciler-Basralı dilciler, Kufeli nahivciler-Kufeli dilciler, Mısırlı dilci ve nahivciler, Kareviyyûn dilci ve nahivcileri ve son olarak Endülüslü dilci ve nahivciler (bu başlıklar altında) konu edilmektedir. Eserin 358/970 yılından (42 yaşından) sonra kaleme alındığı, Zübeydî'nin hocası Muhammed b. Yahyâ er-Rayyâhî'nin vefat ettiği bilgisinin kitapta zikredilmesinden anlaşılmaktadır (Zübeydî, 1984, s. 314).

1.3.3. Lahnü'l-'âmme: Bu eser, “Kitâbün mâ telhanu fîhi'l-'âmme" ismiyle de bilinmektedir (el-Yemânî, 1406, s. 307). Bu isme sahip eserlerin ortak noktası, asırlar öncesine dayanan Arapçanın standart yapısı ile müelliflerin yaşadıkları dönemki dil yapısı arasındaki değişiklikleri ele almalarıdır. İlk dönem standart yapıdaki sözlüklerin yazılış maksadı Arapçanın fasih olarak isimlendirilen formunu tespit ederek kayıt altına almak olmuştur. Zübeydî ve diğer bazı dilcilerin yaptığı bu tür araştırmalar ise dilin sosyolojik boyutunu tarihsellikle birleştirebilmiştir (Zübeydî, 2000, s. 6). Eserin yazılış amacına uygun olarak kullanılan istişhadlar da Arapçanın en temel kaynaklarından oluşmaktadır. Bu kapsamda 26 ayet, 52 hadis, 33 mesel/akvâlü'l-'arab ve 417 şiir beytiyle toplamda 528 kadar istişhad materyalinden istifade edilmiştir (Zübeydî, 2000, s. 344-392).

1.3.4. Kitâbu'l-vâhıh: Bu eser, "Kitabu'l-1̂zâh" ismiyle de bilinir (el-Mağribî,, 1955, s. I/255). (Ulaşılabildiği kadarıyla) Kaynaklarda zikredilen rivayetlerin tamamına yakını, bu kitabın Zübeydî’ye ait olduğu bilgisini vermektedir. Ancak Yâkût el-Hamevî (626/1229), yaşadığı dönemdeki bazı kimselerin, bu eserin Zübeydî̀nin babasına ait olduğunu söyledikleri aktarır. Ancak Hamevî, bu rivayeti kesin bir bilgiden ziyade bir söylenti bağlaminda zikreder (el-Hamevî, 1993, s. VI/2519).

İbn Hallikân (681/1282), Vâdıh'ın oldukça faydalı bir eser olduğu yorumunu yapmıştır (İbn Hallikân, 1972, s. IV/372). Onun bu yorumda bulunması, muhtemelen eserin pedagojik bakımdan dönemin standartlarının üstünde tasarlanmasından kaynaklanmaktadır. Zehebî’ye (748/1348) göre Zübeydî’nin veliaht prens II. Hişâm'a Arapça öğretmesi ile bu eseri yazması arasında anlamlı bir ilişki mevcuttur (Zehebî, 1985, s. XVI/417). Diğer bir ifadeyle eser, hükümdarın talebi üzerine yazılmıştır. İslam topraklarının en batısını temsil eden bu topraklarda kaleme alınan Vâdıh'a (doğuda) konusu, üslubunun akıcılığı ve kaynaklarının yakınlığı bakımından eş değer bir eser gösterilememekle beraber bu yapıt, Zeccâcî'nin Kitâbü'l-Cümel adlı kitabına da benzetilmiştir. Buna göre Zübeydî, 
Zeccâcî'nin el-Cümel' ${ }^{6}$ adlı kitabından etkilenmiş ve Vâdıh'ı kaleme almıştır (Halîfe, 1986, s. 47). Nihâd el-Mûsâ da Arapçayı öğreneceklerin başlangıç aşamasındaki temel kaynaklarının bu iki eser olması gerektiği yorumunda bulunur (Nihâd, 1978, s. 6). İki kitap karşıtsal olarak incelendiğinde Basra ve Kufe ekollerinin görüşlerinde ısrarcı davranmayışları, seçmeci bir yaklaşımla kendilerince uygun olan görüşleri tercih etmeleri, kullandıkları ıstılahların ortak paydada buluşabilmesi ve üsluplarının akıcı ve yalınlığı gibi açılardan büyük oranda benzerliğe sahip oldukları söylenebilir.

Zübeydî̀ye ait olan veya ona nispet edilen diğer kitapların isimleri ise şu şekildedir: Kitâbü'l-'ebniye, Risâletü'l-intisâr li'l-Halîl, Hetkü sutûri'l-mulhidîn, er-Reddü 'alâ ibn Meserre (ed-Dabbî, 1967, s. 66; el-Hanbelî, 1986, s. IV/418; İbn Hallikân, 1972, s. IV/372; Zehebî, 1985, s. XVI/418; el-Kıftî, 1982, s. III/108; Neysâbûrî, 1983, s. 80-81).

\section{KITÂÄ̈'L-VÂDIH İSIMLI ESERDE ZÜBEYDÎ'NIN ARAPÇANIN ÖĞRETIMINDEKİ PEDAGOJIKK YÖNÜ}

Bu başlık altında Vâdıh isimli yapıt belli bazı açılardan incelenerek Zübeydî'nin pedagojik bakımdan yabancı dil öğretim anlayışı üzerinde durulacaktır.

\subsection{Yöntem, Tertip ve Düzen}

Vâdıh'ın yöntem ve sistematik yapısı, alimler tarafından kendisine benzetilen ve incelendiğinde de ciddi benzerliklere sahip olduğu anlaşılan Ebu'l-Kâsım ez-Zeccâcî'nin Kitâbü'l-Cümel'i üzerinden anlatılabilir. el-Cümel eseri incelendiğinde konuların belli bir düzen ve tertibe dahil edilmeksizin işlendiği açıkça görülmektedir. Dilin imla, fonoloji, sentaks ve morfoloji gibi alanlarını içeren konular, eserde birbirinden kopuk ve bağlantısız şekilde düzenlenmiştir. Örneğin, imla kuralları 12 başlık altında işlenirken bu başlıklardan ilki 257. sayfada, son konu başlığı ise 417. sayfada yer alır. 160 sayfa aralığında bulunan toplam başlık sayısı ise 65'tir (Zeccâcî, 1984, s. 449-452). Buradan hareketle Zeccâcî'nin, eserindeki konuların tertibine gerekli özeni göstermediği söylenebilir. Vâdıh'a bakıldığında ise meselelerin olabildiğince birbiri ile bağlantılı ve ilişkili şekilde işlendiği görülür. İmla ve ses bilgisi konularını kitabın bütününe serpiştiren Zeccâcî'nin aksine Zübeydî, bu konuları (büyük oranda) eserinin son bölümlerinde işlemiştir.

Yöntem açısından Vâdıh, âmil teorisi dikkate alınarak düzenlenmiştir. Âmil teorisine işaret eden ve eserini (el-Kitâb) bu teoriye göre tanzim eden ilk kişi Sîbeveyhi'dir. el-Kitâb adlı eserinde âmil teorisinin mantığına vurgu yapan (kelimelerin son harflerinin harekelenmesinde başat rol oynayan unsur) Sîbeveyhi, bu teoriyi cümle örnekleri üzerinden açılamıştır (Sîbeveyhi, 1988, s. I/12-13,34). Bu minvalde diğer bir tanımlamayı ise Abdü'lKâhir Cürcânî (471/1078-79) yapmıştır. Cürcânî, âmilleri "kelime sonlarındaki harflerin hareke bakımdan nasıl bir oluşum içinde olacağını tayin eden yapılar" şeklinde tanımlarken nazım teorisine işaret etmiştir (Havârizmî, 1998, s. 21). Âmil teorisi her ne kadar bazı alimlerce eleştirilmişse de (özellikle) klasik dil perspektifinde nahvin konu ve kurallarının tanzim edilip anlaşılması noktasında vazgeçilmez bir çatı vazifesi üstlenmiştir (Bulut, 2006,

\footnotetext{
${ }^{6}$ Zeccâcî́nin doğum tarihi hakkında herhangi bir bilgiye ulaşılamasa da vefat tarihi 337/949 yılı olarak zikredilir. Ayrıca el-Cümel isimli eserini de seyahat yerlerinden birisi olan Mekke de kaleme aldığı nakledilir (Suyûtî, 1964, s. II, 77). Öte yandan Zübeydî ise 316/928 yılında doğup 379/989 yılında vefat etmiştir. Tarihsel açıdan birbirine muasır olarak kabul edilebilen bu iki dilciden Zeccâcî, Zübeydî'den 40 yıl kadar önce vefat etmiştir. Kaynaklarda bu iki eserin yazılış tarihleri hakkında herhangi bir tarihe rastlanılamasa da iki müellifin yaşadıkları süre zarfları ve eserlerinin içeriği Zübeydî’nin Zeccâcî'den etkilenme ihtimalini desteklemektedir.
} 
s. 69-70). Zübeydî de eserindeki konuları işlerken âmil teorisini dikkate almış; gerek yöntem gerekse tertip ve düzen bakımından olabildiğince sistematik şekilde hareket etmeye gayret göstermiştir.

\subsection{Kullanılan Terminolojik Kavramlar}

Zübeydî, günümüzde alışık olarak kullanılan Arap dili terminolojik yapısından farklı bazı kavramlar kullanabilmiştir. Bu kavramlar sırasıyla şu şekildedir;

2.2.1. Cer (الجَر): Harf-i cerler, Arapçada tek başlarına anlamları olmayan; fiil ve isimlerle kullanılarak sözcüklere ek anlamlar katabilen unsurlardır. Cer kavramı ise kelimenin sonunun i'rab açısından kesra hale dönüştürülmesi işlemidir. Zübeydî, cer kavramına karşılık hafd (الخَفْضض) kavramını kullanmayı tercih etmiştir (Zübeydî, 2011, s. 6166). Günümüzde kullanılan cer kavramı Basra dil mektebine, hafd kavramı ise Kûfe dil mektebine dayanır (el-Ezherî, 2016, s. 19; er-Râcihî, 1993, s. I/82).

2.2.2. Cem' (الجَمْعَ): Cem', sayısal olarak ikiden fazla ismi ifade etmek üzere kullanılan çoğul bir kiptir. Günümüz Arap dili kavramları arasında da cem'i müzekker ve cem'i müennes gibi şekillerde cem' kavramı kullanılmaktadır. Zübeydî de cem' kavramına ek olarak, eşdeğer yapıda cemî‘ (الجَمِيع) kavramını kullanır (Zübeydî, 2011, s. 209). Bu kavram dışında Zübeydî, (isimlerdeki) çoğulları da farklı isimlendirmelere tabi tutabilmiştir. Arap dilcileri arasında ortak bir kabul olarak çoğullar, kurallı ve kuralsız olarak ikiye ayrılır. Modern Arap dili literatürü ve Zübeydî́nin kullanımıyla kuralsız çoğullar, cem'i teksîr ( جَمْ النَكَْسير) olarak isimlendirilir. Kurallı çoğullar ise günümüz Arap dili literatüründe cem’i

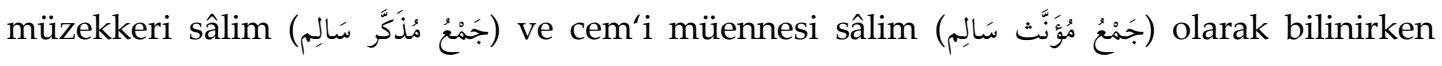

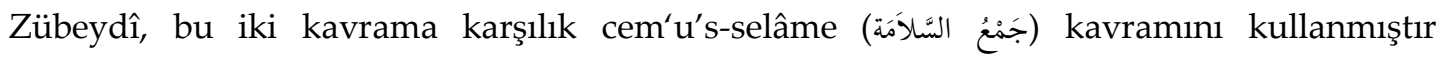
(Zübeydî, 2011, s. 102).

2.2.3. Lâ en-nâfiye li'l-cins (لا النافيَّة للجنُْْ): Bu yapının görevi, cinsinin hükmünü olumsuz hale dönüştürmektir. Günümüzde böylesi bir isimlendirmeye sahip bu kavram Zübeydî tarafından aynı işlevsellikte التبرئة kavramı ile ifade edilmiştir. Modern ve yaygın isimlendirme, Basra dil ekolüne dayanmaktadır. التبرئة kavramı ise Kufe dil ekolünce

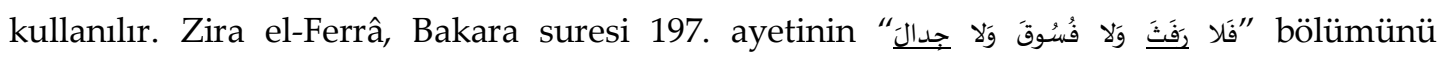
(Mücahid dışında) tüm kurranın tebri'e ile nasb halde okuduğunu bildirmiştir (el-Ferrâ, [t.y.], s. I/120). Zübeydî ise bu konuyu anlatırken " الا رَجْلَ في الدار harfi olduğunu; رجل sözcüğünün ise tebri'e sebebiyle nasb konumda bulunduğunu bildirir (Zübeydî, 2011, s. 111).

2.2.4. Fiillerin zaman kipleri (أزْمِنَة النِعْل): Arapça modern gramer sisteminde fiillerin zaman kipleri, mazi, muzari ve emir olmak üzere üç kısma ayrılır. Mazi fiiller, faaliyeti devam etmeyen ve geçmişte kalan eylemleri; muzari fiiller şimdiki ve geniş zamandaki eylemleri; emir kipi de yapılması emredilen eylemleri zamansal olarak karşılar (Yaşar, 1996, s. 19). Zübeydî ise bu kipleri mazi, müstakbel ve dâ'ime (الدائمة) şeklinde üçe ayırır. Mazi fiiller, gerçekleşen eylemleri; müstakbel fiiller, gerçekleşmesi beklenen eylemleri; dâ'ime fiiller ise içerisinde bulunulan zaman diliminde gerçekleşen eylemleri ifade eder (Zübeydî, 2011, s. 49-50). Öte yandan emir kipi "emir ve nehy" babı altında müstakil bir başlık altında ele alınmıştır (Zübeydî, 2011, s. 85-88).

SEFAD, 2019; (42): 177-196 
2.2.5. Sifat (الصِفَة): Sıfat, uyduğu ismi niteleme görevine sahip kelimedir (İbn Fâris, 1979, s. VI/115; İbn Manzûr, [t.y.], s. II/99-100). Na't kavramı, klasik dil perspektifinde sifat konusuyla kullanım açısından eş değerdir (Nahle, 1994, s. 73-76). Zübeydî sıfat kavramı yerine na't kavramını eserinde benimsemiştir (Zübeydî, 2011, s. 64-65). Na't kavramı da Ferrâ ve mensubu olduğu Kufe dil ekolünün kullandığı bir isimlendirmedir (Ferrâ, [t.y.], s. 145-146).

2.2.6. Ma'nevî te'kîd (التَوكيد المَعْنَوي): Na't, hakîkî ve sebebî olarak ikiye ayrilır. İsimdeki sıfata delalet eden na't çeşidine hakîkî; isim ve sıfat arasındaki ilişkinin ele alındığı na't çeşidine ise sebebî na't denir (el-Galâyînî, 1993, s. III/221-222). Zübeydî, na't'ın bu iki çeşidini "na't" babinda ele alır. Ancak na't konusunun hemen devamında نَعْتُ التَّْْيص ve نَعْتُ الإِحَاطَة ve ara başlıklarına yer verir. Bu başlıklarda ele alınan konular ise manevi te'kîd konularıdır (Zübeydî, 2011, s. 64-67). Sîbeveyhi, te'kîd kavramına karşılık sıfat kavramını kullanmıştır (Sîbeveyhi, 1988, s. II/351,359). Müberred açısından na't kavramı ile sıfat kavramlarının kullanımı eşdeğerdir (el-Müberred, 1994, s. IV/105).

2.2.7. Zamir (الضَمير): İsimlerin yerini tutan marife kelimelere zamir denir. Zübeydî, bu kavrama karşılık الكناية kavramını kullanır (Zübeydî, 2011, s. 72). Zamir kavramı Sîbeveyhi ve temsilcisi olduğu Basra ekolüne ait bir kullanımdır. Sîbeveyhi zamir kavramı yanında eş değer olarak المُضْمِ kavramını da kullanabilmektedir. (Sîbeveyhi, 1988, s. II/385; el-Kavzî, 1981, s. 174). Kinâye kavramı ise Ferra ve onun mensubu olduğu Kufelilere özgü bir isimlendirmedir (Ferrâ, [t.y.], s. I/5).

2.2.8. Nâibü'l-fâ'il (نائبَ الفَاعِل: Eylem bildiren cümlelerde aslolan, fiili gerçekleştiren fail/faillerin bulunmasıdır. Ancak bazen fiiller edilgen yapıda gelebilir ve meful veya mefulün yerini tutan başka bir öge fail görevini üstlenebilir. Bu yapılar, günümüz gramer sisteminde nâibü'-fâ'il olarak bilinir (Yaşar, 1996, s. 249-250). Zübeydî ise nâibü'-fấil kavramı yerine "المَفعول الذي لمْ يُسَمَ فاعِلْهَ" (faili zikredilmeyen merfu meful) isimlendirmesini kullanır. Bu kaidenin açıklaması şu şekildedir; "meful üzerine bir eylem gerçekleştirip failini zikretmediğinde mefulü merfu kıl ve mefule irab bakımından fail muamelesinde bulun. (Bu minval

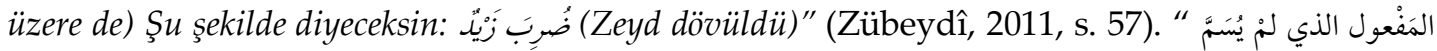
"فِعلُه. kavramı ilk olarak Ferrâ tarafından kullanılmıştır (Ferrâ, [t.y.], s. II/210). Nâibü'l-fâ‘il kavramını ilk kullanan kimse ise ibn Mâlik'tir (eş-Şâfi'î, 1997, s. II/61). Zübeydî'nin tercih ettiği isimlendirmenin anlamsal açıdan daha pedagojik bir yapıda olduğu söylenebilir. Failin yerini tutan ögeye "faili zikredilmeyen meful" dendiğinde bu ıstılahı duyan hemen herkes, bu kavramla hangi konunun ele alındığını tahmin edebilir. Öte yandan nâibü'-fấil kavramı ise daha kısa bir isimlendirmeye sahiptir.

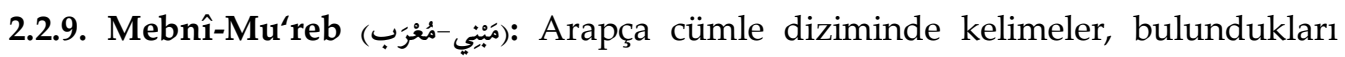
görevlere göre sesli ve/veya sessiz harf bakımından değişimlere maruz kalırlar. Bu değişim (i'râb), kelimenin cümle içinde hangi göreve tayin edildiğini temsil eder. Ancak i'râb değişiminin zahiren olabildiği gibi takdiren olduğu durumlarda mevcuttur. Bunun en temel nedeni de kelime yapısının değişime müsait olup olmayışından kaynaklıdır. Bu bakımdan

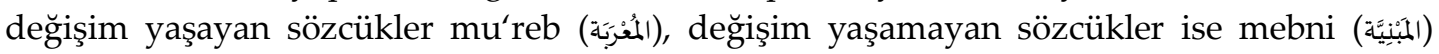
olarak isimlendirilir (Maksudoğlu, 1969, s. 122-123; Yaşar, 1996, s. 217). Zübeydî, mu'reb kavramını kullanmakla beraber mebni kavramı yerine gayrü'l-mu'reb (غير المُمْرَّة) kavramına eserinde yer verir (Zübeydî, 2011, s. 81-82). 
2.2.10. Temyîz (التَمْيز): Cümle veya sözcükteki belirsizliği gidermek üzere kullanılan isme temyîz denir. Zübeydî, temyiz kavramına karşılık gelen tefsîr (التفسير) kavramını kullanmıştır (Zübeydî, 2011/ 117). Bu kavramı tefsir olarak isimlendiren ilk kimse ise

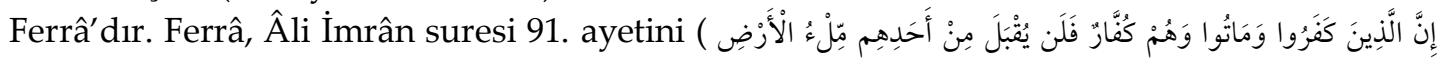

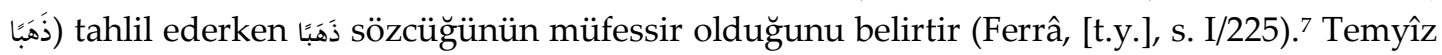
kavramı da ilk olarak (التئيين kavramı ile beraber) Müberred tarafından kullanılmıştır (Müberred, 1994, s. III/32).

\section{3. İstişhadlar ve Örnek Cümleler}

Arap dili kurallarının klasik literatürde anlatımında kendisine istişhad denen delil niteliğindeki örnekler, vazgeçilmez unsurlardandır. İstişhadın beslendiği temel alanlar ise Kur'an-1 Kerim, hadis, şiir ve nesir (ata sözleri, hutbe, mektup vb.)'dir (Bedeva, 2019, s. 314319). Zübeydî de, gramer ekseninde bir eser tasarlamış olsa da verdiği örnekler klasik istişhad anlayışından olabildiğgince uzaktır. Zira Vâdıh'a bakıldığında sadece 11 adet şiir örneği ile karşılaşılır. Bunlardan 10 tanesi "kervanbaşı namesi ve şiir iradında kafiye vecihleri" (بابُ وُجوهِ الْقَوافي في الْإنشادِ وَالْحُحَدَاء) isimli başlık altında yer alır (Zübeydî, 2011, s. 299302). Ele aldığı konu itibariyle bu başlık altında şiir istişhadlarının kullanılması gayet anlaş1lır bir durumdur. Diğer şiir örneği ise bir nahiv konusu olan كَاد ve عَسَى hakkındadır (Zübeydî, 2011, s. 149-150). Ancak bu türde bir konunun anlatımında şiirle istişhadda

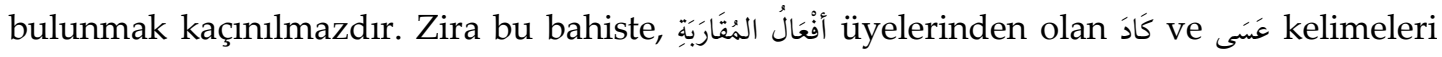
sonrasında gelecek fiilin أن edatı alıp almayacağı meselesi söz konusu edilir. Başta Sîbeveyhi olmak üzere, Basra dil ekolüne mensup dilcilerin cumhur görüşüne göre (istisnai durumlar hariç) أن عَادَ vedaten sonraki fiillerin öncesine gelmemelidir (Sîbeveyhi, 1988, s. I/158; el-Mâlikî, 2008, s. I/516-517). Bu düşünceye sahip olan Zübeydî de “ لا يَحْسُنُ إِدخالُ الفِعْل إِلاً عِنْدَ "الضَرورَة (şiir zarureti dışında كاد fiili sonrası أن edatının kullanılması hoş olmayacaktır) şeklindeki açıklamasına ek olarak şiirle istişhadda bulunmak mecburiyetinde kalmıştır. Bu tür istisnai durumlar haricinde Zübeydî, kullanımı yaygın ve kolay, hedef kitlenin içerisinde bulunduğu hayat şartına uygun örnekler seçmeye azami önem göstermiştir.

Zübeydi'nin şiir ile istişhadda bulunmayışı, onun Edebiyattan haberdar olmadığı ihtimaline de akıllara getirebilir. Ancak bu durum gerçeklikten oldukça uzak bir düşünce olacaktır. Klasik literatürdeki kaynaklar, Zübeydî'nin şiir literatürüne oldukça hakim bir kimse olduğu bilgisini nakleder (İbn Hallikân, 1972, s. IV/372; Humeydî, 1966, s. I/46; Hamevî, 1993, s. VI/2519; et-Temîmî, 1977, s. VI/265). Kadılık vazifesini üstlenebilmesi yönüyle Kur'an ve hadis ilimlerine ve bu alandaki istişhad örneklerine vakıf olması gerekir. Şiir literatürüne hakim olmanın da ötesinde Zübeydî, kendi şiirlerini besteleyen bir şairdir. Ayrıca Zübeydî’nin Vâdıh dışındaki eserlerine bakıldığında onun Edebiyat alanındaki birikimi kolaylıkla anlaşılır. "Lahnü'l-'âmme” adlı eserinin yazılış amacı, Endülüs Arap dili lehçesinin Arapçanın standart yapısından farklılı̆̆ı ve dildeki bu değişimin önlenmesi olduğundan istişhad olarak çok sayıda (toplamda 528 kadar) ayet, hadis ve şiirden faydalanmıştır (Zübeydî, s. 2000). Zübeydî̀nin eserinden etkilendiği Zeccâcî ise dil öğretimi amacıyla yazılmış Cümel eserinde 133 ayet, 2 hadis, 149 şiir, 14 recez beyti ve 10 meselle

\footnotetext{
$\overline{7}$ Ferrâ, tefsîr kavramı ile temyîz kavramını eşdeğer olarak kullanması yanında mefulün li-eclih için de aynı (tefsîr)
} kavramı kullanmıştır. bkz. Ferrâ, [t.y.], s. I, 17.

SEFAD, 2019; (42): 177-196 
toplamda 308 adet şahidi kullanmıştır (Zeccâcî, 1984, s. 423-441). Bu açıdan Vâdıh, benzeri formda tasarlanmış emsallerinden oldukça farklıdır.

Zübeydî'nin konu anlatımlarında vermiş olduğu örnekler de hedef kitlenin günlük hayatı ile iç içe geçmiştir. Oldukça basit ve kısa yapıda cümlelerle kurallar anlatılırken, cümleleri meydana getiren sözcükler de gayet anlaşılır türden seçilmiştir. Bu bağlamda

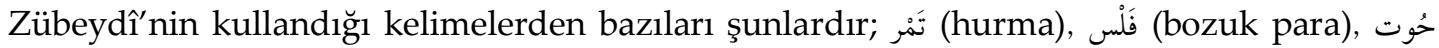

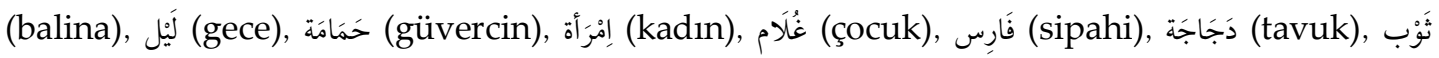

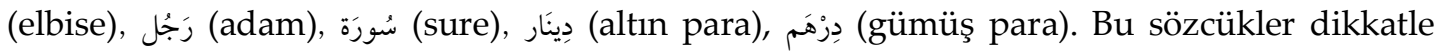
incelendiğinde Zübeydî’nin içerisinde bulunduğu sosyolojik ve coğrafi şartların gerekliliğine son derece sadık kaldığı anlaşılmaktadır. Zira ekonomik bağlamda para birimleri, hayatı idame ettirmede tüketilen gidalar (özellikle Endülüs'ün etrafının denizlerle çevrili yapısı ve balığın temel gıda kaynağı olması), gündelik hayatta sıkça karşılaşılan canlılar ve onların cinsleri Zübeydî'nin örnek cümleleri içerisindeki sözcüklerin ana temalarını oluşturur.

\section{4. Üslup}

Eserde hakim olan ve en dikkat çekici üslub özelliği, konuların söyleşi tarzında anlatılmasıdır. Zira Zübeydî, konuları anlatırken karşısında bir öğrenci varmış gibi, ikinci tekil şahıs kipinde cümleler kullanmayı tercih etmiştir. Böylesi bir üslup, hedef kitleye bir eğitimci karşısında Arapça öğreniyormuş hissi uyandırmaktadır. Bu anlatım yöntemiyle bireysel manada yürütülecek yaygın eğitim faaliyetleri de örgün eğitim atmosferine bürünebilir.

Zübeydî, konu anlatımlarında bazen soru-cevap yöntemine de başvurabilmektedir. Bu duruma "iki fail ve mefulün bir arada toplanmasi" (بابُ جَمْع فاعِلَيْن ومَفْعَلَيَن) konusu aşağıdaki şekilde örnek gösterilebilir;

(Ben Zeyd'i, Zeyd de beni dövdü) diyebilirsin. Bu sözünle şunu

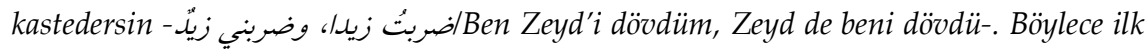
mefulü onu kastetmen dolayısılyla hazfederken diğer fillde isme yakn olması sebebiyle mefulü zikretmiş olursun.... Şunu bilmelisin ki ضصرئبَه وضَرَبنَي زيُّ cümlesini kurman doğru bir kullanım olmayacaktır. Çünkü bir şeyi zikretmediğin müddetçe ona zamirle gönderimde bulunman gerekmez. Eğer bir kişi -nasil oluyor da- ضربني وضربثت زيدًا cümlesini kurabiliyorsun? Zira bu durumda Zeyd ismi henüz zikredilmemesine rağmen ilk fiil olan ضربني dahilinde Zeyd'in zamirine gönderimde bulunuyorsun? (derse) Evet durum bu şekilde (derim), zira ilk fiilin açıklayıcısı sonrasında gelir. Fiiller, faillerini belirten bir cehri/hafi göstergeye (zamirlisim) muhtaçttr. Ancak bu tür durumlarda mefulün zikredilmesi olmazsa olmaz değildir..." (Zübeydî, 2011, s. 209-210).

Zübeydî'nin eserinde kalıplaşmış belli başlı ifade tarzları bulunmaktadır. Konu anlatımlarının başında "إِعَمْ" (bilesin ki...) ibaresine sıklıkla rastlanır (Zübeydî, 2011, s. 102,109,). Aynı manada olan, konu anlatımlarının başında ve sonunda kullanılan diğer bir kalıp ifade ise "فافْهَمَ"dir. Kaideler hakkında verilen örneklerin yeterli olduğunu düşündüğü durumlarda وما أنَْبَة ذلك (ve benzeri örnekler) ifadesiyle konu anlatımı sonlandırır (Zübeydî,

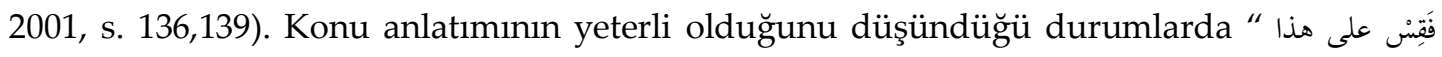

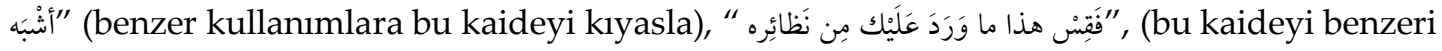




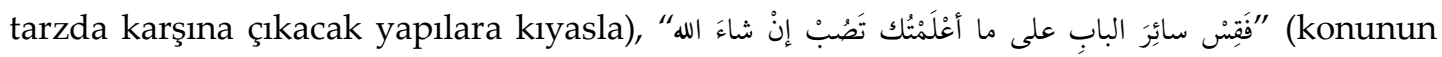
diğer kısmını benim sana öğrettiğim şekle/tarza kıyasla, Allah'ın izniyle doğrusunu

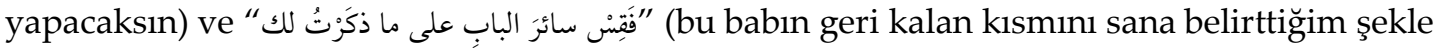
kıyasla) ifadelerini sıkça kullanır (Zübeydî, 2011, s. 111, 125, 159). Ayrıca konu anlatımları sonunda “فافْهَمْ تَصُب إن شاءَ اله" (anla- yıp -, Allah'ın izniyle doğrusunu yapacaksın) ve türevindeki ifadelere de sıklıkla rastlanılır (Zübeydî, 2011, s. 92,103,135,136,139).

Eserin bütününe hakim durumdaki bu anlatım tarzı, Zübeydî’nin pedagojik kaygılar taşıdığının en açık göstergelerindendir. Konu anlatımlarını olabildiğince kısa tutuşu, hedef kitlenin güdülenmesine yardımcı olacak temenni ifadelerine başvurması Zübeydî'nin eseri kaleme aldığı süre boyunca hedef kitleye empati ile baktığını gösterir. Günümüz eğitim sisteminde de özellikle ölçme ve değerlendirme aşamalarında temenni içeren ifadeler kullanılır. Ancak eğitim materyallerinde bu tarz üsluplara rastlanılamamaktadır. Sonuç itibariyle Zübeydî, eserinde sahip olduğu üslupta hedef kitlenin psikolojik ve sosyolojik dokusuna dikkat etmiş, güdülenmelerine hayati derece önem vermiştir.

\subsection{Konuların Ele Alınma Şekli}

Eserdeki konular, sistematik belli bazı işlemler dizisi takip edilerek işlenmektedir. Kimi zaman konu hakkında teorik bilgiler; kimi zaman ise konu ile alakalı örnek sözcük ve cümleler anlatımda merkeze alınır. Buna göre, işlenen konunun kelime/kelime öbekleriyle ilişkili olması halinde bunların hangi ögeler olduğu teker teker yazılır. Bu başlıklar altında teorik bilgiler örnekler beraberinde zikredilir. Bu tür anlatım tarzına verilebilecek örneklerden birisi cem' (çoğullar) konusudur;

"Çoğullar', kurallı ve kuralsız olarak iki kısma ayrılır. Kuralsız çoğulda kelimenin

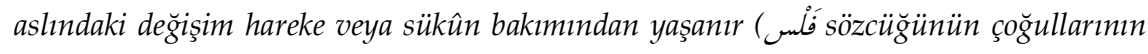

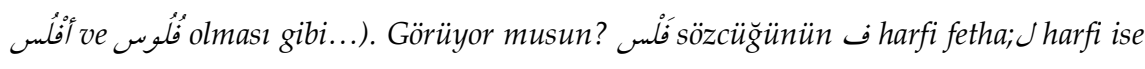
sakinken çoğul yapıya dönüştürüldüklerinde (sesli harfleri) değişime uğradılar. Bu

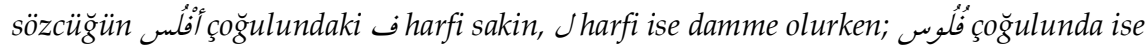
ف harfi damme, J harfi de keza damme olmuş ve bu iki harf arasına garfi girmiştir" (Zübeydî, 2011, s. 102).

Kaidenin kategorik sınıflandırmaya tabi olduğu kimi yerlerde ise ilk olarak kısa teorik bilgiyle konu anlatımı başlar. Ardından ilişkili kelime ve/veya cümle örnekleri verilir. Son olarak da bu örnekler üzerinden irab durumlarına açıklık getirilerek konu tamamlanır. $\mathrm{Bu}$ tür bir anlatım yöntemine ححَّذا konusu örnek verilebilir; "حَّبَ kelimesinin manası övgüdür. Bu

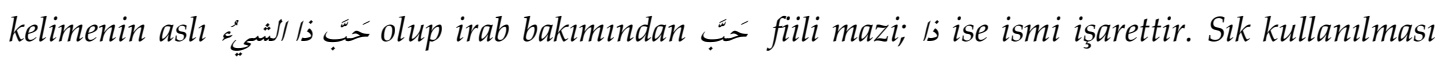
sonucu bileşik yapısından tek bir yapı haline dönüşmüştür. (İşlevsel bakımdan) ذا ذَرَب 'nin durumu

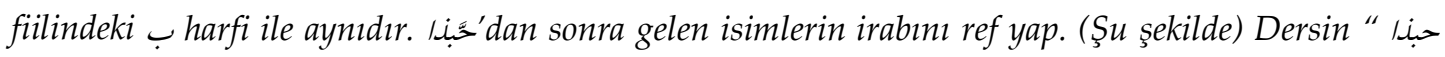

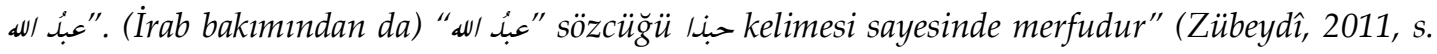
115).

Kategorik sınıflandırmanın söz konusu olduğu konularda bazen de teorik bilginin akabinde irab özelliğine ve ilgili örneklere geçilebilmektedir. İrab bilgisinin öncelendiği bu tür durumlarda genellikle irabın değişmeyen bir yapısından söz edilir. Buna "fiillerde zaman" konusu örnek gösterilebilir;

SEFAD, 2019; (42): 177-196 
"Fiiller üç çeşit zaman kipine sahiptir. Bunlardan ilki olan mazi kipte, kelimelerin sonu

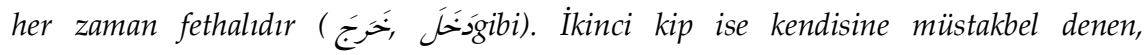

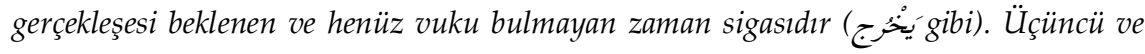
son zaman kipi ise içinde bulunduğun vakit ile henüz sona ermemiş ve faaliyeti kesilmemiş eylemleri ifade eder (ئَ gibi). Cezm ve nasb eden herhangi bir âmil gelmediği müddetçe kelime sonları muhakkak merfu halde olacaktır" (Zübeydî, 2011, s. 49-50).

Zübeydî'nin kategorik sınıflandırmalı kaidelerin izahatında izlediği ve bu araştırmada üzerinde durulacak son anlatım tarzı ise şu şekildedir. Kuralların kaç sınıfa ayrıldığı örneklerle anlatılıp sonrasında kuralın mantığı örnekler üzerinden açılanır. Bu tür bir anlatıma "hafd edatları" başlığı altındaki açılamalar örnek verilebilir; "Bu edatlar; harfler,

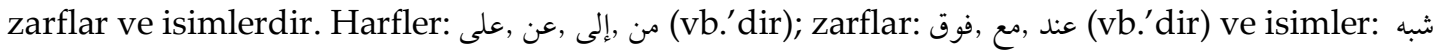
شبيه ,بعض ,مثل (vb.'dir). Bu edatlar kendilerinden sonra gelen isimleri cer duruma getirir. (Şu

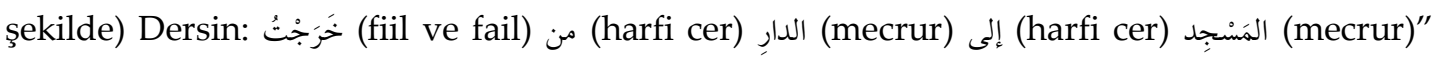
(Zübeydî, 2011, s. 59-60).

\subsection{Sesli Harflerin Gerektiğinde Belirtilmesi}

Yazılı dil formunda Arapça, sesli harfleri kendi bünyesinde bulundurmayan bir dil yapısına sahiptir. Zira Arapçanın yüzyıllardır kullandığı alfabe Fenikelilerin yazı sisteminden alınmıştır. Fenikeliler ise alfabelerinde sesli harflere yer vermemektedir (Akerson, 2008, s. 50-56). Durum böyle olunca sessiz harflere sahip olmayan Arapçanın yabancı bir dil olarak öğrenilmesi ve yazılı materyallerin okunabilmesi oldukça zor bir hal almıştır. Dini kaygılardan ötürü de Ebu'l-Esved ed-Düelî (69/688) tarafından sesli harfleri karşılamak üzere bazı noktalama işaretleri uygulanmıştır (İbnü'n-Nedîm, [t.y.], s. 45-47; ibnü'l-Enbârî, 1971, s. 39). Pedagojik açıdan Arapçanın yabancı bir dil olarak öğretilmesi yolunda tasarlanan materyallerin sesli harf bulundurması meselesi de farklı şekillerde uygulamalara tabi tutulmuştur. Bu faaliyetleri üç sınıfta toplamak mümkündür;

-İ'rab ve harekelemenin kısmen yapıldığı uygulamalar,

-İrab ve harekelemenin hiçbir şekilde yapılmadığı uygulamalar,

-İrab ve harekelemenin tamamen yapıldığı uygulamalar.

Görsel ve yazılı alanda Arapça materyallerin sessiz harfleri barındırmaması esastır. Bu sebeple gerçekliğe uygun hareket ederek, içerisinde irab gibi anlamsal meseleleri (irab) ${ }^{8}$ de barındıran harekesiz dil anlayışına uyum sağlanması kaçınılmazdır. Arap dili materyallerinin hedef kitleye harekesizce sunuluşu, onların aşırı derecede zorlanmaları sonucu cesaret ve öğrenme isteklerine set çekebilir. Bu nedenle izlenebilecek en ideal yöntem, sesli harfin materyalde tedrici şekilde azaltılmasıdır. Bu uygulamada da temel kıstas, hedef kitlenin içerisinde bulunduğu dil yeterliliği ve seviyesidir. Ulaşılan yazma eserler incelendiğinde Zübeydî'nin gerekli gördüğü bazı yerlerde harekeleme işlemine müracaat ettiği görülmektedir (Zübeydî, 2011, s. 31,43). Bu sebeple onun kısmi hareke uygulamasına baş vurduğu söylenebilir.

Zübeydi'nin bu tür bir uygulamayı eserinin tamamında değil de belli bazı yerlerinde tercih etmesi, kanaatimizce hedef kitlenin hareke olgusu ile dengeli bir ilişki kurmasını

\footnotetext{
${ }_{8}^{8}$ Cümleyi meydana getiren sözcüklerin son sesli harfleri sözcüklerin sözdiziminde nasıl bir rol oynayacaklarını tayin eder. Bu sebeple i’râb, (özellikle yazı dili itibariyle) Arapça öğrenmede karşılaşılacak ciddi zorlukların başında görülebilir.
} 
sağlamak amaçlıdır. Zira harekelemenin tamamen uygulandığı materyaller, hedef kitleyi ciddi şekilde hazırcılığa sürüklemekte; onların yabancı bir dil olan Arapçaya odaklanmalarını engellemektedir. Harekeye hiçbir şekilde yer vermeyen materyaller ise hedef kitlenin farklılık gösteren yapılarına (yaş, dil seviyesi vb.) hitap edememektedir. Tüm bu sebeplerden ötürü Zübeydî'nin takip ettiği dengeli harekeleme anlayışı pedagojik bir dil perspektifinin ürünüdür.

\subsection{Konuların Bir Bütün Halinde Ele Alınması}

Vâdıh eserinde hakim olan konu içeriği nahiv konularından müteşekkildir. Zübeydî bunu yaparken de dilin semantik, fonoloji ve morfoloji alanların da ihmal etmez. Bu kapsamda i'rab ve anlam ilişkisine de hemen her konu başlı̆ğ altında değinir. Hemzenin halleri, idgâm, mehâricü hurûf ve harflerin sıfatlarına (Cehr, Hems, Şiddet, Raha gibi) değinerek dilin fonetik boyutunu ele almıştır. Morfolojinin karşılığı olan sarf ilmi ise Zübeydî’nin büyük bir ihtimam gösterdiği alandır. Zira sarf, Arap dilinin ölçüsü olarak kabul edilir. Dilin büyük kısmı kıyas ile elde edilir. Bunun gerçekleştirileceği alan ise iştikak ve tasriftir. Arapçanın çekimli yapısı da sarf ilmine vakıf olunmayı çok daha kesin şekilde gerekli kılar. Bu sebepledir ki Sarf, Arap dilinin en önemli ve bir o kadarda kapalı yarısı olarak görülür (Usfur el-İşbîlî, 1987, s. 27-33).

Zübeydî, konuları bir bütün halde ele aldığı gibi bu bütünlüğü iltisaklı parçalara da ayırmayı bilmiştir. Bu duruma "kâne ve benzerleri" konusu örnek verilebilir. " بابُ الأفعال التئي " تَزَفْعُ الأسُماءَ وتَنُُْبُ الخَبَر eserinin 77-79. sayfaları arasında kısaca anlatır. Anlatım içerisinde söz konusu edatların hangileri olduğunu sırasıyla zikrettikten sonra birkaç örnek verme ihtiyacı hisseder. Daha sonra açıklama ve irabını da yaparak konunun temel mantığını genel hatlarıyla anlatmış

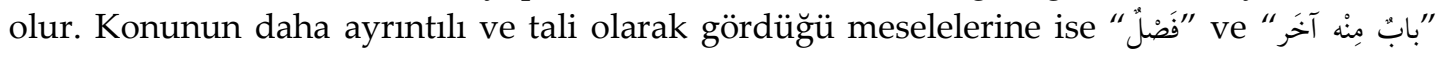
başlıkları altında değinir. Bu anlatım tarzı, çalışmanın tümüne hakim vaziyettedir.

\subsection{Gereksiz Açıklamalara Yer Verilmemesi}

Arap dili, üzerinde uzlaşma sağlanamayan pek çok kuralı dahilinde barındırır. Dilbilgisi kapsamında kaleme alınan eserler bu farklılıklara çeşitli boyutlarda yer vermişlerdir. Merkezinde dilbilgisi kurallarını barındırmasına rağmen Zübeydî, eserinde bu tür ihtilaflardan olabildiğince kaçınmıştır. Örneğin; istisnâ bildiren edatlar, Basra ve Kufe dil mektepleri arasında tartışma konusu olan meselelerden birisidir. Sîbeveyhi, istisnâ edatlarından حاشى nın harf olup kendinden sonraki sözcüğün irab bakımından mecrur olarak amel göreceğini belirtir. Ferra'ya göre bu kelime, faili olmayan ve $J$ harfi hazfolmuş bir fiildir (örn: حاشا لزيد). Müberred ise bu sözcügün hem fiil hem de harf olarak kabulünü muhtemel görür. Kufeliler'in geneli, bu kelimenin mazii bir fiil olduğu kanaatindedir. Basra'llların tercihi ise bu kelimenin harf olduğu yönünde yoğunlaşmıştır (el-Enbârî, 2003, s.

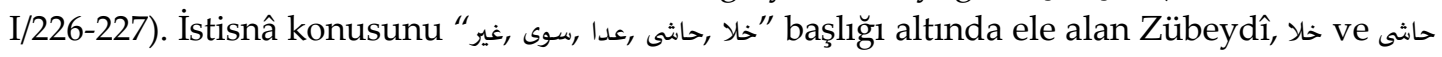
için uzlaşmacı bir yöntem izleyerek (tartışmaya mahal vermeden) şu açılamayı yapar;

"Dilediğinde bu kelimeleri fiil olarak kullanabilir ve ardından gelen sözcü̆g̈̈n irabına nasp şekilde amel edebilirsin. Dilersen de bu yapuları (حاشى ve) harf olarak kabul edebilir ve irabında hafd (cer) olarak amel edebilirsin. (Tercih yapmak istersen de) Bu yapıları birer fiil olarak kullanman daha uygun olacaktır. Zira bu sözcükler, fiil olmaya

SEFAD, 2019; (42): 177-196 
daha elverişlidir (bu kelimelerin حاشى-يحاشى ,خلا-يخلو şeklinde fiil formunda çekimi mümkündür)“ (Zübeydî, 2011, s. 107).

Zübeydî, bu edatların kullanımında muhtemel iki uygulamadan bahsetmiş tercihte bulunmak gerektiğinde de kendi görüşünü belirtmiştir. Böylece her ne kadar istisna edatlarındaki farklı görüşlere atıf yapmış olsa da Zübeydî, gereksiz açıklamalara girmeyerek hedef kitlenin zihnini karıştırmamış, tercihindeki mantığı kısaca açıklamıştır.

İhtilaflı kaidelerden bazısında ise alternatifleri hiç zikretmeden tek bir kullanım şeklinden bahsedebilmiştir. Örneğin; "إنما ,لعلما , edatlarının isimlerinin irab bakımından ref olması gerektiğini bildirmiştir (Zübeydî, 2011, s. 79). Aynı konuda Zeccacî ise nasb ve ref şeklinde irabta amel edilebileceğini söyler. (Zeccâcî, 1984, s. 303). Bu kaidenin anlatımında Zübeydî alternatif kullanımlara yer vermeyi uygun görmemiştir.

Tartışmalı kaidelerde olabildiğince sade bir anlatım tarzını benimseyen Zübeydî, ihtilafın söz konusu olmadığı yerlerde de gayet veciz ve anlaşılır anlatım tarzı

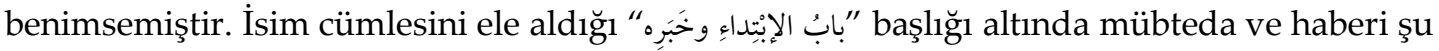
şekilde anlatır; "Kendisi hakkında bir oluş bildirilecek isim (Mübteda) ile cümleye başlarsan ve bu isme herhangi bir (nasp veya cer eden) âmille etki etmezsen irabın merfu yaparsin. Bu isim hakkında

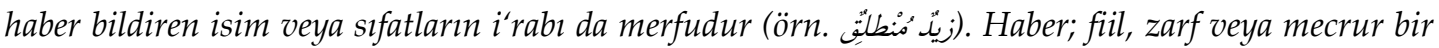
isim çeşitliğinde gelebilir ve böylece ref konumunda bulunur. Zira (bu yapı) mübtedanın haberidir. Haber içerisinde mübtedaya dönen bir zamirin bulunması gereklidir."

Ana başlık altındaki konu anlatımı örnek cümlelerle beraber sonlandırılır. Bu kısa anlatım dışındaki konular (haberin mukaddem olarak mübtedadan önce gelebilmesi, haberin zarf veya ism-i mecrur şekilde gelmesi, zamirlerin erillik-dişilik, tekillik-ikillik-

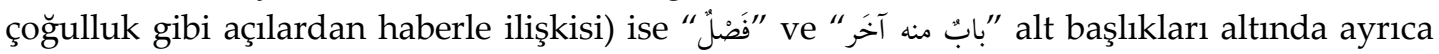
ele alınır (Zübeydî, 2011, s. 70-74).

Vâdıh'ın gereksiz açıklamaları barındırmayışı hakkında verilebilecek son örnek ise Sîbeveyhi'nin el-Kitâb'1 ile karşıtsal olarak şu şekilde aktarılabiir. Nâibü'l-fấ'il konusunu Zübeydî, "faili zikredilmeyen meful" babında şu şekilde ele alır;

$$
\text { باب المفعول الذي لم يسم فاعله: }
$$

"Meful üzerine bir eylem gerçekleştirip de failini zikretmediğinde mefulün irabın merfu

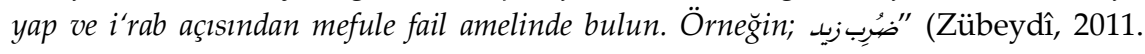

$57)$.

Nahiv ilminin otoritesi olarak kabul edilen Sîbeveyhi'nin el-Kitab adlı eserinde ise aynı konu "Eylemin failinin mefule müteaddî olduğu meful" başlı̆̆ altında şu şekilde işlenir;

$$
\text { زاعلم إلمفعول الذي تعداه فعله إلى مفعول: }
$$




\begin{abstract}
"Bilmelisin ki failin yaptığ eylemin mefule yüklendiği ve yüklenmediği durumlar bulunur. Her iki durumda da mana, eylemin ayn kişi üzerinde tesirinin gerçekleşmesiyle sonuçlanır. Şu şekilde dediğini fark etmedin mi? Zeydi dövdüm (failin eylemi mefule müteaddî yapılmamaktadır). Bu cümledeki mefulü kullanmayıp şu şekilde dersin: Zeyd dövüldü. Bu cümlede ise meful fiile müteaddi olmadı ve iki cümlenin de manalarn ayn oldu" (Sîbeveyhi, 1988, s. I/42).
\end{abstract}

Sonuç olarak Zübeydî, kullanımı az olan kavram ve sözcüklerle anlatımı uzatmayı tercih etmemiş, döneminde olabilecek en sade ifadelerle konuları özetlemiştir. Ayrıca Zübeydî'nin diğer eserlerinin incelenmesi halinde Vâdıh eseri adına gösterdiği pedagojik önem çok daha net anlaşılacaktır.

\title{
2.9. Dil Mektepleri Arasında Tercih Yapılması
}

Bir dilcinin hangi dil ekolünden etkilendiğini anlamanın belli bazı emareleri mevcuttur. Bunların başında da kullanılan terminolojik kavramlar ve kuralları açıklama şekilleri gelir. Zübeydî, gerek Kufe gerekse Basra dil ekollerinin terminolojilere eserinde yer vermiştir. Bu açıdan onun kavramsal alanda dil ekolleri arasında tercihte bulunduğu görülmektedir. Istılahlar gibi kaidelerin anlatımında da Basra ve Kufe ekollerinin değişen görüşlerine eserinde yer vermiştir. "Anlatımda sadelik" temel prensibi gereği dil ekollerinin farklılaşan görüşlerinden (olabildiğince) daha kolaylarıyla Arap gramerini anlattığı kanaatimizce söylenebilir. Bu duruma verilecek örneklerden birisi medh (övgü) fiillerinden

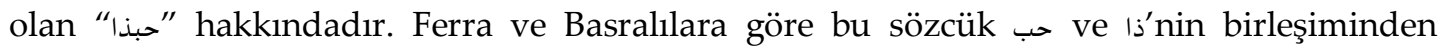
müteşekkil tek bir kelimedir. Bu fiilde cinsiyet ve adet bakımından farklılaşma söz konusu olmaz. Bu kelime ardından gelen isimlerin irab yönünden ameli reftir (Ferrâ, [t.y.], s. I/58; Sîbeveyhi, 1988, s. II/180). Sîbeveyhi ise hocası Halil b. Ahmed ve kendisinin bu konudaki görüşünü şu şekilde nakleder; "Allah kendisine rahmetiyle muameleye eylesin ki (Hocam) el-Halil, şeklinde iki yapıyı kendisinde barındırdığını düşünmekteydi. Ancak (benim kanaatimce) ذاحب ve birbirine geçmiş tek bir sözcüktür.... Bu kelime zamirleri de kendinde açıkça göstermez" (Sîbeveyhi, 1988, s. II/180).

"نعموا رجالاً " Kufeliler ve onun en önde temsilcilerinden Kisai'ye göre medh fiilleri örneğinde olduğu üzere, zamirleri kendisinde gösterir (Enbârî, 2003, s. I/81-82; İbn Ya'îş, [t.y.], s. VII/127; Catal, 1996. 117). Zübeydî ise حَبَّذا önın övü manasında olup aslının

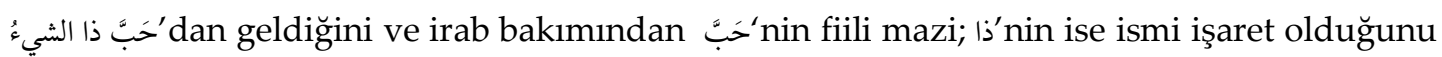
belirtir. Bu bileşik yapı sık kullanılması sonucu tek bir yapı haline dönüşmüştür (Zübeydî, 2011, s. 115). Zübeydî'nin bu görüşü, el-Halil ve Sîbeveyhi'nin görüşünün ortasında bir bakış açısıdır.

Ele aldığı konular hakkında kendisinde önceki dilcilerin görüşlerinden haberdar olmayışından ötürü bu tür bir faaliyeti benimsediği ihtimali de akıllara gelebilir. Ancak قال بَعُُْهم (bir grup dilci iddia etti ki...) زعم قوم (berin geneline bakıldığında kullanmış olduğu (dilcilerden bazısı dedi ki)9 , والذي قدمتُ أحبُّ إلي (aktardı̆̆ım bu görüş en beğendiğimdir) gibi

\footnotetext{
${ }^{9}$ Hemzenin vasıl durumu ile ilgili konuyu ele alan Zübeydî, vasıl durumunda harekenin ayne'l-fiile tabi olması

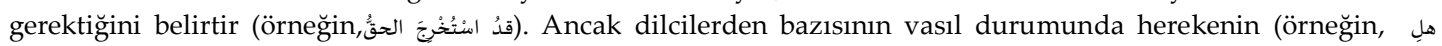
kesra olması gerektiği yönündeki düşüncesine atıf yapar. Kendi tercihini de ilk kullanımdan yana kullanır (Zübeydî, 2011, s. 133). Zübeydî'nin ilk naklettiği bilgi Kufeliler, ikinci bilgi ise Basralılara ait bir gramer yorumudur (İbnü'l-Enbârî, 2003, s. II/ 606). Buradan hareketle "dilcilerden bazısı" olarak isimlendirilen kişilerin Basra dil ekolüne mensup oldukları anlaşılır.

SEFAD, 2019; (42): 177-196
} 
ifadeler onun diğer bakış açılarından haberdar olduğu ve pedagojik olarak bu görüşler arasında tercihte bulunduğunun en temel göstergelerindendir.

\section{SONUÇ}

Zübeydî, Vâdıh isimli eserini kaleme almada mümkün olduğunca pedagojik gereklilikleri yerine getirmeye gayret etmiştir. Bu bağlamda ulaşılan sonuçları maddeler halinde şu şekilde sıralayabiliriz;

Zübeydî'nin Vâdıh isimli eseri, salt manada bir nahiv kitabından ziyade dili bütün olarak değerlendiren bir eserdir. Bu yapıt, dahilinde fonetik, morfoloji, sentaks ve semantik gibi dilin temel ve bütüncül alanları barındırır.

Vâdıh eseri, konularının ele alınışı itibariyle âmil teorisine göre düzenlenmiştir. Kaidelerin takibini âmil teorisi tayin ederken her bir konu, mevcut zorluğuna göre de birbirine bağlantılı parçalara ayrılmıştır. Bu sayede öğrenilmesi daha öncelikli olan bilgilerle ayrıntılı kabul edilecek bilgiler tek düze şekilde birleştirilmez. Günümüz eğitim sistemindeki materyallerde ise konular olabildiğince tek bir başlık altında anlatılır.

Üslup açısından konuların anlatımında Zübeydî, karşısında bir öğrenci varmış edasıyla konuları anlatır. Bu üslup, günümüz eğitim anlayışında kendisine neredeyse rastlanılamayan bir tarzdadır. Zübeydî'nin benimsediği bu türde bir söylem özelliği, onun hedef kitlenin psikolojik dokusuna gösterdiği özeni temsil eder.

Vâdıh, içerisinde; Endülüs devletinin o dönemki fiziki, coğrafi, ekonomik ve sosyal unsurlarını barındırmaktadır. Konuların anlaşılmasına yönelik verilen örnekler, Endülüs'te yaşayan ve eğitim seviyesi yüksek olmayan kişilerin dahi anlayacağı sadeliktedir. İçerisinde yaşanılan hayat üzerinden Arapçanın anlatılması, günümüz eğitim sisteminde çok fazla rastlanılamayan durumlardandır. Bu bağlamda özellikle Arapçanın öğretimini dini bir eğitim bağlamında değerlendiren eğitimciler, tasarladıkları materyallerde de hedef kitleye gerekli empatiyle yaklaşamamaktadırlar.

Geçmişte ve günümüzde sıkça rastlanan istişhad kültürü Zübeydî'nin kendine özgü yapısıyla yaklaştığı alanlardandır. Eserinin yazılış amacı Arap dili mantığını öğretmek olduğundan ayet, hadis, şiir ve edebi bazı kapsamlardaki istişhadlar Zübeydî'nin eğitim anlayışına uymamaktadır.

Hedef kitlenin dil öğrenirken motive olması ve güdülenmesi Zübeydî’nin eğitim anlayışının temel unsurlarındandır. Bu sebeple de Zübeydî, yazılı dilde sesli harfleri belirtmek adına, tedrici hareke faaliyetlerine başvurmuştur. Günümüz eğitim faaliyetlerinde ise (genellikle) bu türde dengeli yaklaşımlardan ziyade harekeleme işlemi ya tamamen yapılmakta ya da hiç uygulanmamaktadır.

Ciddi ve engin bilgi birikimine sahip bir dilci olan Zübeydî, Vâdıh eserini kaleme alırken bu bilgi yeterliliğini ispatlama çabasına hiçbir zaman meyletmemiştir. Kufe'liler ve Basralılar arasındaki tartışmalara girmekten mümkün oldukça kaçınmış, böyle bir durum olduğunda ise isimlerini alenen zikretmemiştir. Bu tür bir yaklaşım sergilemesi, kanaatimizce hedef kitlenin dikkatini öncelikli konulara çekme isteğinden kaynaklıdır. İhtimalleri minimize ederek hedef kitlenin yalnızca dil öğrenmesine; dilin tartışmalı meselelerinden (ilk etapta) haberdar olmamasına ve zihinlerinin karışmamasına azami çaba sarf etmiştir. 


\section{SUMMARY}

Abû Bakr al-Zubaidî is an important scholar known in the history of Islamic culture. The main theme of this research is the work of the Kitâbu'l-Wâdıh written by this person who has worked in many different fields. A descriptive narrative method was followed and Zubaidî's work was compared with other works written for the same purpose. In this way, the difference between Zubaidî's understanding of education in the past and present has been made clear.

Zubaidî tried to fulfill the requirements of pedagogical language understanding as much as possible when designing his work al-Wâdıh. In this context, we can summarize the results achieved as follows;

Zübaidî's Wâdıh is a work that takes the language as a whole, rather than simply the book of grammar. It contains basic and holistic fields of language such as phonology, morphology, syntax and semantics.

The work of Wâdıh has been designed according to the theory of the influences/'avâmils. The order in which the grammatical rules are to be processed is determined by the theory of influences, and each subject is divided into pieces connected to each other according to their current difficulty. In the materials of today's education system, the subjects are explained under a single title as much as possible.

In terms of the expression style he uses in his work, Zubaidî treats the subjects as if they are students. This style reflects a structure that is almost unrecognized in today's education. This manner of discourse that Zubaidî adopts represents his attention to the psychological fabric of the target group.

The book of Wâdıh has the physical, geographical, economic and social elements of the Andalusian state at that time. The examples given to the understanding of the subjects are simple to understand even by the people living in Andalusia and not having a high level of education. Explaining the Arabic language through the life of the target group is one of the conditions that cannot be encountered in the education system of today. In particular, educators who evaluate the teaching of Arabic in the context of a religious education cannot approach the target group with empathy in the materials they design.

The testimony culture, which is common in the past and today, is one of the areas that Zubaidî approaches with its unique structure. The verses, hadiths, poems and the testimonies in the literary field do not follow the Zübaidî's understanding of education because Zubaidî's aim in writing the book is to teach the logic of the Arabic language.

Motivation of the target group while learning language is a key element of Zubaidî's understanding of education. For this reason, in order to indicate vowels in written language, he gradually applied punctuation marks. In today's educational activities, two extreme approaches (usually) are shown in the implementation of punctuation marks.

Zubaidî is a linguist with a serious and profound knowledge. In writing the work of Wâdıh, he did not attempt to prove his background information. He avoided the controversies between the grammarians of Basrah and Kufa, and he did not explicitly mention clearly their names when this happened. The fact that Zubaidî has such an approach is due to his desire to draw the attention of the target group to the priority subjects for learning the language.

SEFAD, 2019; (42): 177-196 


\section{KAYNAKÇA}

Akerson, F. E. (2008). Türkçe Örneklerle Dile Genel Bir Bakış (2. bs.). İstanbul: Multilingual.

Amayira, İ. (1996). Buhûsün fi'l-İstişrâki ve'l-Lugati (1. bs.). "et-Tefkîrü'l-Lügaviyyi't-Türâsî Beyne't-Te'sîl ve't-Ta'lîm”, Beyrut: Müessesetü'r-Risâle.

Bedeva, A. (2018). İ̉n 'Âşûr'un Tefsirinde İstişhâd Yöntemi. Bingöl Üniversitesi İlahiyat Fakültesi Dergisi (11), 311-331.

Bulut, A. (2006). “İbn Madâ'nın Arap Dilindeki Amil Nazariyesine Yönelik Eleştirileri”. Nüsha 6 (23): 62-74.

Catal, M. (1996). Nusûs ve Mesấilu Nahviyye ve Sarfiyye. Haleb: Müdîriyyetü'l-Kütübi ve'lMecmû'âti'-Câmi'1yye.

Dayf, Ş. (1967). el-Medârisü'n-Nahviyye (7. bs.). Kahire: Dâru'l-Me'ârif.

ed-Dabbî, E. C. (1967). Buğyetü'l-Mültesim fî Târîhi'r-Ricâli Ehli'l-Endelüs. Kahire: Dârü'lKâtibi'l-'Arabî.

el-Enbârî, K. (2003). el-İnsâfu fî mesâili'l-Hilâf Beyne'n-Nahviyyîn: el-Basriyyîn ve'l-Kûfiyyîn C. I (1. bs.). Beyrut: Mektebetü'l-Asriyye.

el-Ezherî, H. b. 'A. (2016). Şerhu'l-Mukaddemeti'l-Acuriyye fì Usûli 'ilmi'l-'Arabiyye li't-Tullâb ve'l-Mübtedi'în. 'Â. ebu'l-'Abbâs (Yay. haz.). Kahire: Dâru't-Talâ'i'.

el-Ferrâ, Y. b. Z. [t.y.]. Me'âni'l-Kur'ân (1. bs.). A. Y. en-Necâtî (Yay. haz.). Misır: Dârü'lMisriyyeti li't-Te'lîf ve't-Terceme.

El-Galâyînî, M. (1993). Câmi'u'd-Durûsi'l-'Arabiyye C. III (18. bs.). Beyrut: el-Mektebtü'l'Asriyye.

el-Hamevî, Y. (1993). Mu'cemü'l-Üdebâ C. VII (1. bs.) . İhsan Abbas. Beyrut: b.y.y.

el-Hanbelî, A. (1986). Şezerâtü'z-Zeheb fì Ahbâri men Zehebe (1. bs.). M. el-'Arnavûd (Yay. haz.). Dimaşk-Beyrut: Dâru İbn Kesîr.

el-Havârizmî, K. (1998). Kitâtü Terşîhi'l-'illel fí Şerhi'l-Cümel (1. bs.). 'Â. M. S. el-Umeyri (Yay.haz). Mekke: Ma'hedü'l-Buhûsi'l-'İlmiyye ve İhyâ'i't-Türâsi'l-İslâmî.

el-İşbîlî, İ. 'U. (1987). el-Mümti'u fi't-Tasrîf C. I. (1. bs.). F. Kabbâve (Yay. haz.). Beyrut: Daru'lMa'rife.

el-Kavzî, 'A. (2003). el-Mustalahu'n-Nahvî (1. bs.). Riyad: 'Imâdetü Şu' ûni'l-Mektebât.

el-Mağribî, E. H. (1955). el-Muğribü fì Hule'l-Mağribi C. I. (2. bs.). Ş. Dayf (Yay. haz.). Kahire: Dârü'l-Me'ârif.

el-Mûsâ, N. (1978). Müstedrek 'Alâ Kitâbi'l-Vâdih li'z-Zübeydî (1. bs.). Amman: b.y.y.

el-Müberred, E. 'A. (1994). el-Muktedab C. IV. (1. bs.). M. 'A. Udeyme (Yay. haz.). Kahire: Vizâratü’l-Evkâf.

el-Yemânî, A. (1406). İşâretü't-Ta'yîn fì Terâcimi'n-Nuhâti ve'l-Lügaviyyîn (1. bs.). 'Abdülmecîd Diyâb Merkezü'l-Melik Faysal li'l-Buhûs ve'd-Dirâsâti'l-İslâmiyye (Yay. haz.), y.y.: b.y.y.

el-Yezîdî, Y. b. M. (1978). Kitâbü'l-Emâlî (1. bs.). Haydarabad: Matba'atü Cem'yyeti Dâireti'lMe'ârif.

en-Neysâbûrî, 'A. S. (1983). Yetîmetü'd-Dehr Fî Mehâsin Ehli'l-'Asr C. II. (1. bs.). M. Kamiha (Yay. haz.). Beyrut: Darü'l-Kütübi'-'Illmiyye.

er-Râcihî, F. R. (1993). Şerhu'l-Makûdî 'Alâ el-Fiyeti İbn Mâlik C. I. y.y.: Camiatü'1-Kuveyt. 
es-Seyyid, E. 'A. (1971). “Ebû Bekir ez-Zübeydî”. Âdâbü'r-Râfidîn (1), 123-151.

es-Suyûtî, C. (1964). Buğyetü'l-Vü'ât C. I, F. İbrâhim, 'Îsâ el-Bâbî el-Halebî. Lübnan: b.y.y.

es-Suyûtî, C. (1987). el-Muzhir fî 'Ulûmi'l-Lugati ve Envâ'ihê C. I. M. C. El-Mevlâ, M. F. İbrâhim ve M. A. El-Bacâvî (Yay. haz.). Beyrut: Menşûrâtü'l-Mektebeti'l-'Asriyyeti.

eş-Şâfi'î, E. 'İ. (1997). Hâşiyetü's-Sabbân 'Alâ Şerhi'l-'Eşmûnî li-'Elfiyeti İbn Mâlik C. II. (1. bs.). Beyrut: Dâru'l-Kütübi'l-'Ilmiyye.

et-Temîmî, E. S. 'A. (1977). el-'Ensâb C. VI. A. b. el-Mu'allimî (Yay. haz.). y.y.: Dâiratü'1Me'ârifi'l-‘Osmâniyyeti.

ez-Zeccâcî, 'A. b. İ. (1984). el-Cümel fi'n-Nahv (1. bs.). A. T. el-Hamd (Yay. haz.). y.y.: Müessesetü'r-Risâle.

ez-Zehebî, Ş. b. K. (1985). Siyerü A'lâmi'n-Nübelâi (3. bs.). Mecmû'atü Mine'l-Muhakkikîn Bi'işrâfi'ş-Şeyh Şu'ayb el-Arna' ût (Yay. haz.). y.y,: b.y.y.

ez-Zübeydî, E. B. (1984). Tabakâtü'n-Nahviyyîn ve'l-Lugaviyyîn (2. bs.). M. E. F. İbrâhim (Yay. haz.). y.y.: Dârü'l-Me'ârif.

ez-Zübeydî, E. B. (2000). Lahnü'l-'Âmme/Lahnü'l-'Avâm (3. bs.). R. Abdüttevvab (Yay. haz.). Kahire: Mektebetü'l-Hancî.

ez-Zübeydî, E. B. (2011). Kitâbü'l-Vâdıh (2. bs.). A. Halife (Yay. haz.). Umman: Dâru Celîsi'zZamân.

Feyrûzâbâdî, M. (2000). el-Bülga. M. el-Mısrî (Yay. haz.). Dimaşk: Dâru's-Sa'âdeti.

Halîfe, A. (1986). Teysîrü'l-'Arabiyyeti Beyne'l-Kadîm ve'l-Hadîs (1. bs.). Ürdün: Menşûrât Mecma'i'l-Lügati'l-'Arabiyyeti'l-Ürdünî.

Humeydî, M. (1966). Cezvetü'l-Muktebes fì Zikri Vülâti'l-Endelüs. Kahire: ed-Dârü'l-Misriyye li't-Te'lîf ve'n-Neşri.

İbn Fâris, E. H. (1979). Mu'cemu Mekâyîsi'l-Luga C. VI. 'A. M. Hârûn (Yay. haz.). Dimaşk: Dârü'l-Fikr.

İbn Hallikân, E. A. (1972). Vefeyâtü'l-'A'yân ve Enbâü Enbâi'z-Zamân C. II, IV. İ. Abbas (Yay. haz.) Beyrut: Dâru Sâdır.

İbn Kûtiyye, M. (1989). Târîhu Ifftitâhi'l-Endelüs. İ. el-Enbârî (Yay. haz.). Kahire: Dârü'lKitâbi'l-Misrî.

İbn Manzûr, E. F. [t.y.]. Lisânu'l-'Arab C. I. Beyrut: Dâru Sâdır.

İbn Ya'îş, E. B. [t.y.]. Şerhu'l-Mufassal C. I. Kahire: İdâretü't-Tibâ'ati'-Münîriyye,

İbnu'l-Enbari, E. B. (1971). el-Vakf ve'l-İbtidâ. M. A. Ramazan (Yay. haz). Dimeşk: Matbû'âtu Mecma'i'l-Lügati'l-'Arabiyye bi-Dimeşk.

İbnu'l-Enbari, E. B. (1985). Nüzhetü'l-Elibbâ fî Tabakâti'l-Üdebâ (3. bs.). İ. es-Sâmirrâî (Yay. haz.). Ürdün: Mektebetü'l-Menâr.

İbnü'l-Kıftî, C. (1982). İnbâhu'r-Ruvvât 'Alâ Enbâhi'n-Nuhât C. III. E. F. İbrahim (Yay. haz.). Beyrut: Dârü'l-Fikri'l-'Arabî.

İbnü'n-Nedîm, E. F. [t.y.]. el-Fihrist, R. el-Mâzindârî (Yay. haz.). y.y.: b.y.y.

Kılıçlı, M. (1986). Arap Edebiyatında Şu'ûbiyye. Doktora Tezi. Erzurum: Atatürk Ü.

Maksudoğlu, M. (1969). Arapça Dilbilgisi. Ankara: Ankara Üniversitesi İlahiyat Fakültesi Yayınları.

SEFAD, 2019; (42): 177-196 
Nahle, M. A. (1994). el-İsmü ve's-Sıfatü fi'n-Nahvi'l-'Arab̂̂ ve'd-Dirâsâti'l-'Ûrubbiyye, İskenderiye: Dârü'l-Ma'rifeti'l-Câmi'1yyeti.

Özdemir, M. (1995). “Endülüs”. Türkiye Diyanet Vakfi İslam Ansiklopedisi C. XI. İstanbul: Türkiye Diyanet Vakfı Yay. 211-225.

Özdemir, M. (1997). “Endülüs'ün Yıkılış Sürecinde Öne Çıkan Bazı Hususlar". Ankara Üniversitesi İlahiyat Fakültesi Dergisi, 36 (1), 233-254.

Sîbeveyhi, ‘A. b. ‘O. (1988). el-Kitâb C. I-II. (2. bs.). 'A. M. Hârûn (Yay. haz.). Kahire: Mektebetü'l-Hancî.

Ya'kûb, B. (1971). Mevsû'atü 'Ulûmi'l-Lügati'l-'Arabiyye C. VIII. Lübnan: Dârü'l-Kütübi'l‘llmiyye.

Yaşar, A. (1996). Arapçanın Temel Kuralları (Sarf-Nahiv) (2. bs.). Diyarbakır: Anadolu Matbaacilık.

Yıldırım, A. (2007). Endülüs'te Arap Dili Çalışmaları. Yüksek Lisans Tezi. Van: Yüzüncü Yıl Ü. 